\title{
FAKTOR-FAKTOR DALAM GLOBALISASI DAN PEMBANGUNAN
}

\author{
NURHARPANI \\ Sekolah Tinggi Ilmu Hukum Padang \\ nurharpani@gmail.com
}

\begin{abstract}
The COVID-19 pandemic has created the need and need to maintain social distance in social interactions (social distancing), quarantine, and isolation so that every vulnerable individual will not be exposed to the virus. The use of technology with online meetings for students and educators is very important, especially in the development of civic education, in order to love the Republic of Indonesia. This paper will discuss the concept and direction of civic education and the urgency of strengthening the concept and direction of progressive citizenship education online in the midst of the covid-19 virus pandemic. The method used in this research is descriptive analytical with a qualitative approach. The results show, First, the concept of Citizenship Education supports the objectives of civic education, which can be interpreted as a subject that focuses on the formation of citizens who have intellectual skills, skills to participate in every civic activity and have a strong civic character so as to make citizens who are intelligent and have character. . Second, the urgency of strengthening the concept and direction of progressive citizenship education online in the midst of the covid-19 virus pandemic prepares students to become good citizens who master knowledge derived from multidisciplinary concepts and theories, practice values, and apply the skills they need to participate. in online education.
\end{abstract}

Keywords: Factors, Globalization, Development.

Abstrak: Pandemi covid-19 telah menciptakan kebutuhan dan perlunya menjaga jarak dalam interaksi sosial (social distancing), karantina, dan isolasi sehingga setiap individu yang rentan tidak akan terkena virus. Pemanfaaatn teknologi dengan pertemuan secara daring bagi peserta didik dan pendidik sangat penting, terutama dalam pengembangan pendidikan kewarganegaraan, agar mencintai Negara Republik Indonesia. Tulisan ini akan membahas tentang konsep dan arah pendidikan kewarganegaraan dan urgensi penguatan konsep dan arah pendidikan kewarganegaraan progresif secara daring di tengah pandemi virus covid-19. Metode yang digunakan dalam penelitian ini adalah deskriptif analitis dengan pendekatan kualitatif. Hasil penelitian menunjukan, Pertama konsep Pendidikan Kewaranegaran mendukung tujuan dari pendidikan kewaranegaran, dapat diartikan sebagai mata pelajaran yang fokus pada pembentukan warga negara yang memiliki keterampilan intelektual, ketrampilan berpartisipasi dalam setiap kegiatan kewarganegaraan dan memiliki karakter kewarganegaraan yang kuat sehingga menjadikan warga negara yang cerdas dan berkarakter. Kedua, urgensi penguatan konsep dan arah pendidikan kewarganegaraan progresif secara daring di tengah pandemi virus covid-19 mempersiapkan siswa menjadi warga negara yang baik yang menguasai pengetahuan yang berasal dari konsep dan teori multidisiplin, mempraktikan nilai-nilai, dan menerapkan keterampilan yang mereka butuhkan untuk berpartisipasi dalam pendidikan secara daring.

Kata Kunci: Faktor, Globalisasi, Pembangunan.

\section{A. Pendahuluan}

Pandemi covid-19 telah menciptakan kebutuhan dan perlunya menjaga jarak dalam interaksi sosial (social distancing), karantina, dan isolasi sehingga setiap 
individu yang rentan tidak akan terkena virus. Dalam keadaan normal, pembelajaran model belajar dari rumah dan belajar dari sekolah atau perguruan tinggi bisa relatif sama tujuan dan kualitasnya. Perbedannya mungkin hanya sarana pendukung yang digunakan. Pada keadaan darurat, ketika masyarakat (termasuk siswa dan guru) masih dibayangi wabah mematikan covid-19, seharusnya desain dan proses pembelajaran yang diterapkan berbeda sebab belajar tidak lagi bisa dianggap sebagai business as usual (Romadlon, 2020). Walaupun demikian, kebijakan model belajar dari rumah yang diputuskan dengan tujuan untuk menghambat penyebaran virus dalam praktiknya tetap harus mengacu pada kurikulum nasional yang digunakan.

Pemerintah Republik Indonesia segera mengeluarkan Peraturan Pemerintah (PP) No. 2 Tahun 2020 tentang Pembatasan Sosial Berskala Besar dalam Rangka Percepatan Penanganan Corona Virus Disease 2019 (Covid-19) dan Keputusan Presiden Republik Indonesia No. 11 Tahun 2020 tentang Penetapan Kedaruratan Kesehatan Masyarakat Corona Virus Disease 2020 (Covid-19). Sementara Kementerian Pendidikan dan Kebudayaan menerbitkan dua surat edaran terkait pencegahan dan penanganan virus tersebut. Pertama, Surat Edaran Nomor 2 Tahun 2020 tentang Pencegahan dan Penanganan Covid-19 di lingkungan Kemendikbud dan Surat Edaran Nomor 3 Tahun 2020 tentang Pencegahan Covid-19 pada Satuan Pendidikan (Martaria Rizky Rinaldi, 2020).

Menteri Pendidikan dan Kebudayaan Nadiem Anwar Makarim dalam siaran pers tanggal 12 Maret 2020, menyampaikan Surat Edaran Nomor 3 Tahun 2020 tentang Pencegahan Covid-19 yang menginstruksikan untuk segera mengoptimalkan peran Usaha Kesehatan Sekolah atau unit layanan kesehatan di perguruan tinggi dengan cara berkoordinasi dengan fasilitas pelayanan kesehatan setempat dalam rangka pencegahan penyebaran Covid-19 (Martaria Rizky Rinaldi, 2020).

Kesiapan pengajar dan yang diajar dalam memanfaatkan teknologi pembelajaran, khususnya pada jenjang pendidikan menengah, relatif baik dan terus meningkat kualitasnya. Namun, muatan pembelajaran daring masih perlu terus disempurnakan agar lebih interaktif sehingga memungkinkan siswa dapat lebih terlibat (engaged) dalam proses pembelajaran (Romadlon, 2020). Daya dukung teknologi juga perlu terus ditingkatkan kualitasnya, sebagaimana fasilitas yang digunakan perusahaanperusahaan penyedia konten (content provider).

Kekurangsiapan pengajar dan manajemen sekolah dan perguruan tinggi serta minimnya deliberasi yang disebabkan terbatasnya waktu persiapan yang diberikan, menyebabkan kebijakan model belajar dari rumah menuai kritikan/keluhan dari sebagian masyarakat. Sebagian masyarakat mengeluhkan model belajar dari rumah, sebagai kegiatan memindahkan aktivitas kelas dari sekolah ke rumah dengan beban/tugas yang bahkan lebih banyak. Hal ini juga ditemukan dalam Pendidikan Kewarganegaraan.

\section{B. Metodologi Penelitian}

Pada hari ini tantangan penguatan konsep dan arah Pendidikan Kewarganegaraan harus lebih kuat. Kenapa hal ini dipertanyakan? Pada hari ini setiap anak didik dari Sekolah Dasar sampai dengan Perguruan Tinggi, bisa berselancar ke dunia mana saja pada hari ini. Misalnya anak Sekolah Dasar menonton film-film yang merusak ketidakcintaanya pada negara ini di Video-video yang bertebaran di Youtube atau pun Website dan Media Sosial, sedangkan untuk Mahasiswa di Perguruan Tinggi, bisa 
mengakses informasi-informasi yang tidak bisa difilter oleh mereka, sehingga hilangnya kecintaan mereka pada tanah air ini. Artikel ini akan membahas terkait urgensi penguatan konsep dan arah pendidikan kewarganegaraan secara daring di tengah pandemi virus covid-19, sehingga bisa menumbuhkan konsep kecintaan siswa dan mahasiswa pada Negara Kesatuan Republik Indonesia.

\section{Hasil dan Pembahasan}

\section{Faktor Dalam Globalisasi Dan Pembangunan}

Sebelum kita masuk pada konsep dan arah dan pendidikan kewarganegaraan, maka kit masuk dulu pada tujuan pendidikan kewarganegaraan. Tujuan dari Pendidikan Kewarganegaraan adalah agar peserta didik memiliki kemampuan sebagai berikut (Arif Prasetyo Wibowo, 2017): a) berpikir secara kritis, rasional dan kreatif dalam menanggapi isu kewarganegaraan; b) berpartisipasi secara aktif dan bertanggung jawab, dan bertindak secara cerdas dalam kegiatan bermasyarakat, berbangsa dan bernegara, serta anti-korupsi; c) berkembang secara positif dan demokratis untuk membentuk diri berdasarkan karakter-karakter masyarakat Indonesia agar dapat hidup bersama dengan bangsa-bangsa lain; dan d) berinteraksi dengan bangsa-bangsa lain dalam percaturan dunia secara langsung atau tidak langsung dengan memanfaatkan teknologi informasi dan komunikasi.

Selain itu konsep dari pendidikan kewarganegaraan secara umum meliputi aspek-aspek sebagai berikut (Setiawati, 2016):

a) Persatuan dan kesatuan bangsa, meliputi hidup rukun dalam perbedaan, cinta lingkungan, kebanggaan sebagai bangsa Indonesia, sumpah pemuda, keutuhan Negara Kesatuan Republik Indonesia, partisipasi dalam pembelaan negara, sikap positif terhadap Negara Kesatuan Republik Indonesia, keterbukaan dan jaminan keadilan;

b) Norma, hukum dan peraturan, meliputi tertib dalam kehidupan keluarga, tata tertib di sekolah, norma yang berlaku di masyarakat, peraturan-peraturan daerah, norma-norma dalam kehidupan berbangsa dan bernegara, sistem hukum dan peradilan nasional, hukum dan peradilan internasional;

c) Hak Asasi Manusia, meliputi hak dan kewajiban anak, hak dan kewajiban anggota masyarakat, instrumen nasional dan internasional HAM, pemajuan penghormatan dan perlindungan HAM;

d) Kebutuhan warga negara, meliputi hidup gotong royong, harga diri sebagai masyarakat, kebebasan berorganisasi, kemerdekaan mengeluarkan pendapat, menghargai keputusan bersama, prestasi diri, persamaan kedudukan warga negara;

e) Konstitusi negara, meliputi proklamasi kemerdekaan dan konstitusi yang pertama, konstitusi-konstitusi yang pernah digunakan di Indonesia, hubungan dasar negara dengan konstitusi;

f) Kekuasaan dan politik, meliputi pemerintahan desa dan kecamatan, pemerintahan daerah dan otonomi, pemerintah pusat, demokrasi dan sistem politik, budaya politik, budaya demokrasi menuju masyarakat madani, sistem pemerintahan, pers dalam masyarakat demokrasi;

g) Pancasila, meliputi, kedudukan pancasila sebagai dasar negara dan ideologi negara, proses perumusan pancasila sebagai dasar negara, pengamalan nilainilai pancasila dalam kehidupan sehari-hari, pancasila sebagai ideologi terbuka; dan 
h) Globalisasi, meliputi: globalisasi di lingkungannya, politik luar negeri Indonesia di era globalisasi, dampak globalisasi, hubungan internasional danorganisasi internasional, dan mengevaluasi globalisasi.

(Achmad Sanusi, 2013) menyebutkan bahwa konsep-konsep pokok yang lazimnya merupakan tujuan Civic Education pada umumnya adalah sebagai berikut: a) Kehidupan kita di dalam jaminan-jaminan konstitusi; b) Pembinaan bangsa menurut syarat-syarat konstitusi; c) Kesadaran warga negara melalui pendidikan dan komunikasi politik; d) Pendidikan untuk (ke arah) warga negara yang bertanggung jawab; e) Latihan-latihan berdemokrasi; f) Turut serta secara aktif dalam urusanurusan publik; g) Sekolah sebagai laboratoriun demokrasi; h) Prosedur dalam pengambilan keputusan; i) Latihan-latihan kepemimpinan; j) Pengawasan demokrasi terhadap lembaga-lembaga eksekutif dan legislatif; dan k) Menumbuhkan pengertian dan kerjasama Internasional.

Jika berkaca pada konsep yang dikemukakan terkait konsep pendidikan kewarganegaraan, maka bisa kita bahwa arah dari Pendidikan Kewarganegaraan memuat beberapa hal, yang memuat nilai-nilai karakter. Untuk mencapai arah tersebut Pendidikan Kewarganegaraan memiliki komponen-komponen yaitu pengetahuan kewarganegaraan (civic knowledge), keterampilan kewarganegaraan (civic skill), dan karakter kewarganegaraan (civic disposition) yang masing-masing memiliki unsur (Winataputra, 2012). Berdasarkan pemaparan di atas dapat dikemukakan bahwa arah dari tujuan dari Pendidikan Kewaranegaran dapat diartikan sebagai mata pelajaran yang fokus pada pembentukan warga negara yang memiliki keterampilan intelektual, ketrampilan berpartisipasi dalam setiap kegiatan kewarganegaraan dan memiliki karakter kewarganegaraan yang kuat sehingga menjadikan warga negara yang cerdas dan berkarakter.

Mengaca pada perkembangan teknologi pada hari ini dan perkembangan Virus Covid 19, yang makin menyebar keseluruh penjuru Indonesia, maka proses belajar mengajar dipaksa berpuasa yaitu dilakukan secara daring dari rumah masing-masing. Guru atau Dosen dan siswa atau mahasiswa dipaksa untuk melakukan kegiatan belajar mengajar atau perkuliahan dari rumah masing-masing. Faktanya, terdapat ketidaksiapan baik fisik, infrastruktur maupun psikologis sehingga kegiatan tersebut hanyalah pemberian tugas kepada peserta didik dan meminta mereka mengumpulkan dalam kurun waktu tertentu. Tugas memang sebuah kewajaran dalam proses pemebelajaran, akan tetapi akan menjadi tidak wajar bila dipaksakan demi mengejar sebuah absensi pertemuan atau perkuliahan (Sheilla Varadhila Peristianto, 2020).

Bangsa yang berkualitas didapatkan dari pendidikan yang berkualitas. Kaum terdidik tidak hanya cerdas secara intelektual akan tetapi kaum terdidik haruslah mempunyai nurani untuk memperbaiki kehidupan berbangsa dan bernegara yang damai dan aman. Oleh karena itu, moralitas dan intelektualitas bagaikan dua sisi mata uang yang tidak bisa dipisahkan sebagai tujuan utama penyelenggaraan pendidikan (Santosa, 2020). Maka dari itu menurut penulis, perlu urgensi penguatan konsep dan arah pendidikan kewarganegaraan secara daring di tengah pandemi virus covid-19. Tentu hal ini terlihat dari keresahan orangtua dan pemerintah makin banyaknya anak, pemuda generasi penerus bangsa ini yang menyebarkan berita hoax (kebohongan) atau bahkan menonton dan membaca berita-berita atau informasi yang merusak kecintaanya pada Negara Kesatuan Republik Indonesia. 
Seharusnya pendidikan kewarganegaraan hadir untuk mengisi kekosongan tersbeut, serta mengajarkan kepada siswa dan mahasiswa sebagai generasi penerus bangsa, untuk mencintai negeri ini sebagai salah satu bentuk kewajiban dari warga negara Republik Indonesia. Salah satunya dengan megenalkan Pendidikan kewarganegaraan Progresif (Rusnaini, 2020). Pendidikan kewarganegaraan Progresif diyakini sebagai arah baru pendidikan kewarganegaraan yang berkontribusi membangun masa depan berkelanjutan di Indonesia. Model ini mendorong siswa tak hanya menguasai teori sebagai warga negara yang baik tetapi juga menerapkannya dalam kehidupan sehari-hari. Pendidikan kewarganegaraan Progresif merupakan program pendidikan yang membahas tentang masalah kebangsaan, demokrasi, dan civil society (masyarakat madani) yang dalam implementasinya menerapkan prinsipprinsip pendidikan dan kemanusiaan (Candrawati, 2020).

Pendidikan kewarganegaraan progresif mempersiapkan siswa menjadi warga negara yang baik yang menguasai pengetahuan yang berasal dari konsep dan teori multidisiplin, mempraktikan nilai-nilai, dan menerapkan keterampilan yang mereka butuhkan untuk berpartisipasi dalam pendidikan secara daring di tengah virus Covid 19 (Rusnaini, 2020). Program Pendidikan kewarganegaraan yang efektif penting dalam memberikan siswa ataupun mahasiswa kesempatan untuk mengembangkan karakternya di rumah ataupun lingkungan sekitarnya. Pendidikan kewarganegaraan progresif tidak hanya pada kurikulum saja tetapi juga harus menumbuhkan suatu perubahan sosial yang meningkat, meluas, dan berkelanjutan selama periode waktu tertentu baik secara kuantitatif maupun kualitatif.

\section{Penutup}

Hasil penelitian menunjukan, Pertama konsep Pendidikan Kewaranegaran mendukung tujuan dari pendidikan kewaranegaran, dapat diartikan sebagai mata pelajaran yang fokus pada pembentukan warga negara yang memiliki keterampilan intelektual, ketrampilan berpartisipasi dalam setiap kegiatan kewarganegaraan dan memiliki karakter kewarganegaraan yang kuat sehingga menjadikan warga negara yang cerdas dan berkarakter. Kedua, urgensi penguatan konsep dan arah pendidikan kewarganegaraan progresif secara daring di tengah pandemi virus covid-19 mempersiapkan siswa menjadi warga negara yang baik yang menguasai pengetahuan yang berasal dari konsep dan teori multidisiplin, mempraktikan nilai-nilai, dan menerapkan keterampilan yang mereka butuhkan untuk berpartisipasi dalam pendidikan secara daring.

\section{Daftar Pustaka}

Achmad Sanusi. (2013). Kepemimpinan Pendidikan: Strategi Pembaruan, Semangat Pengabdian, Manajemen Modern. Bandung: Nuansa Cendekia.

Arif Prasetyo Wibowo, M. W. (2017). Pendidikan Kewarganegaraan: Usaha Konkret untuk Memperkuat Multikulturalisme di Indonesia. Jurnal Civics, 14(2).

Candrawati, K. (2020). Kejenuhan Informasi Terhadap Pengambilan Keputusan pada Masa Pandemi Covid 19. APPTI, 1(1).

Martaria Rizky Rinaldi, R. Y. (2020). Kecemasan pada Masyarakat Saat Masa Pandemi Covid-19 di Indonesia. APPTI, 1(1).

Romadlon, F. (2020). Mendefinisikan Ulang Pola Pembelajaran Daring: Antara Sharing Knowledge dan Transfer Etika. APPTI, 1(1). https://doi.org/10.30560/hssr.v2n2p17 
Rusnaini. (2020). PKn Progresif, Arah Baru Pendidikan Kewarganegaraan Berkelanjutan. Solo: Solopos Perss.

Santosa, A. (2020). Tantangan Demokratisasi Ekonomi di Tengah Pandemi Covid-19: Kajian Kritis Terhadap Ruu Omnibus Law Cipta Kerja dan Program Kartu PraKerja. APPTI, 1(1).

Setiawati, W. (2016). Implementasi Penilaian Keterampilan Kewarganegaraan Berdasarkan Kurikulum 2013. Civicus: Jurnal Pendidikan Kewarganegaraan, 20(2).

Sheilla Varadhila Peristianto, E. A. (2020). Pengelolaan Stres pada Masa Pandemi Covid-19 di Kecamatan Sewon Kabupaten Bantul. APPTI, 1(1).

Winataputra, U. S. (2012). Pendidikan Kewarganegaraan dalam Perspektif Pendidikan untuk Mencerdaskan Kehidupan Bangsa: Gagasan, Instrumentasi, dan Praksis. Bandung: Widya Aksara Press. 